2005

\title{
Identifying Effective Behavior Management in the Early Childhood Classroom
}

Kelly R. Victor

Cedarville University

Follow this and additional works at: http://digitalcommons.cedarville.edu/education_theses

Part of the Pre-Elementary, Early Childhood, Kindergarten Teacher Education Commons

\section{Recommended Citation}

Victor, Kelly R., "Identifying Effective Behavior Management in the Early Childhood Classroom" (2005). Master of Education Research Theses. 11.

http://digitalcommons.cedarville.edu/education_theses/11 


\title{
IDENTIFYING EFFECTIVE BEHAVIOR MANAGEMENT IN THE EARLY CHILDHOOD CLASSROOM
}

\begin{abstract}
A Thesis submitted in partial fulfillment of the requirements for the degree of

Masters of Education
\end{abstract}

By

KELLY RAE VICTOR

B.R.E., Practical Bible College, 2001

2005

Cedarville University 


\section{HEREBY RECOMMEND THAT THE THESIS PREPARED UNDER MY SUPERVISION BY Kelly Rae Victor ENTITLED Identifying Effective Behavior Management in the Early Childhood Classroom BE ACCEPTED IN PARTIAL FULFILLMENT OF THE REQUIREMENTS FOR THE DEGREE OF Master of Education.}
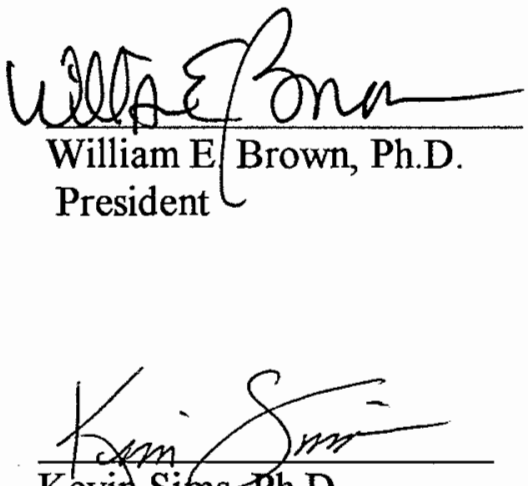

Kevin Sifns, Ph.D.

Dean, School of Social Sciences and Professional Studies

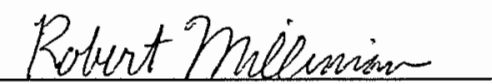
Robert Milliman, Ph.D. Academic Vice President

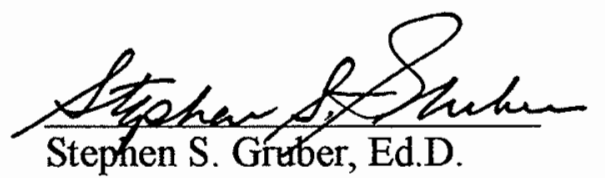

Co-ordinator of the M.Ed. Program 


\begin{abstract}
Victor, Kelly R. M. Ed. Education Department, Cedarville University, 2005. Identifying Effective Behavior Management in the Early Childhood Classroom.

Every educator has a dream to maintain a classroom free from disruptions; one in which each child is being molded, shaped, and corrected in a loving and caring environment that inspires appropriate behavior. The purpose of this research project was to determine how to create an effective behavior management plan and effectively teach classroom management techniques. Students involved in this project were preschoolers age three and four from a local Young Men Christian Association in Akron, $\mathrm{OH}$.
\end{abstract}




\section{TABLE OF CONTENTS}

I. Introductiion $\ldots \ldots \ldots \ldots \ldots \ldots \ldots \ldots \ldots \ldots \ldots \ldots \ldots \ldots \ldots \ldots \ldots \ldots \ldots \ldots \ldots \ldots \ldots \ldots, 5,13$

Educational Significance............................................5- 7

Purpose......................................................... 8

Methodology $\ldots \ldots \ldots \ldots \ldots \ldots \ldots \ldots \ldots \ldots \ldots \ldots \ldots \ldots \ldots \ldots \ldots \ldots \ldots \ldots \ldots \ldots \ldots . . .8$

Biblical Integration.................................................9- 11

Application to Current School........................................11- 12

II. Literature Review........................................................ 14- 41

Development.................................................. 23

The Plan.............................................................. 25

Rules................................................................... 27

Rewards............................................................. 29

Consequences........................................................ 32

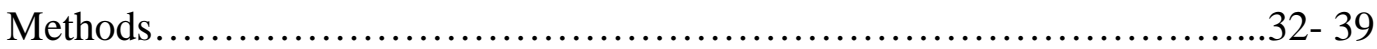

Support System..................................................39-41

III. Procedures and Results...............................................42- 58

Presentation of the Problem...........................................42

Presentation of Hypothesis...........................................42- 43

Subjects............................................................43

Variables............................................................44 
Procedures......................................................44- 52

Results............................................................. 58

IV. Summary and Conclusion............................................ 65

Bibliography........................................................66- 68

Appendices...........................................................68- 73 


\section{ACKNOWLEDGEMENTS}

I would like to give a sincere thank you to my parents for their emotional and financial support throughout my educational endeavors. Their continued prayer and understanding while completing this thesis made it possible to finish.

Sincere thanks to all the prayer warriors at Brown Street Baptist Church in Akron, $\mathrm{OH}$. To all my mom's scrapbooking ladies who have preserved the past, enriched the present, and inspired hope for future. 


\section{DEDICATION}

To my parents and family, for their guidance, love, enthusiasm, and support. To my students and parents for their patience and cooperation. 


\section{INTRODUCTION}

Educational Significance

Every educator has a dream. This dream is that each person be treated with respect, caring, and have the opportunity to learn the skills they need to live a successful life. Educators all hope that each child will by no means feel humiliated but that each one would be able to learn from his or her mistakes. It is about teachers and students working together to create an environment rich in excitement for life and learning. This is necessary to cultivate a sense of safety and securities in the classroom where feelings of inadequacy are no longer a part of the environment.

Classroom management plays a critical role in schools across the nation today. The increase of violence, lawsuits, and classroom disruptions make it necessary for more effective behavior management plans. “According to the Phi Delta Kappa/Gallup Thirty First Annual Poll, the top problems facing our schools are 'lack of discipline/ moral control, and fighting/ violence/ gangs' (Rose\& Gallup, 1999)”, as stated in the fall 2001 edition of American Secondary Education article A Comparison of Elementary and High School Teacher Discipline Styles.

The fact remains that there is no one proven deterrent for disruptions in the classroom. Every situation is different because every child is different. "The major shift is from short term solutions to long term teaching. Practicing positive discipline today 
helps students develop the inner strength and life skills that will help them become successful adults (Nelsen, Escobar, Ortolano, Duffy, Sohocki, 2001).”

There is an abundance of information on the topic of discipline. Much of the information found was in books, journal articles, and the World Wide Web. Journal of American Education, Education Digest, and Journal of Educational Forum are just a few examples of the locations of these books and articles. These resources, which the writer has found, dealt mainly with the different styles, methods, and techniques of classroom management. The three most frequent situations encountered in the classroom are: acts of disruption, acts of defiance, and acts of inattention (Cotton, 1990). A good number of teachers react to inappropriate behavior by shaming, verbally reprimanding, threatening, embarrassing, suspending, and expelling the student (Geiger, 2000). D.A. Almeida has developed five proactive rules which are clarity, consequences, consistency, caring, and change.

In an article by Stephen Papesh entitled “The Five Be’s for Educators” it is suggested that teachers determine what the student is bringing with them to class by their face and physical appearance. Gurian also suggests that the best method of student discipline is to help the child deal with emotional and attachment stress. Papesh suggests that every lesson should be 'special'. Education should be exciting and conducted with enthusiasm. The teacher should act in a professional manner and always remember that he/she is the adult in the classroom and not a teenager. No matter how the students act, the teacher should conduct himself as a mature adult setting an example for them. Letting them know that education never ceases was a resounding theme from Canter, Gurian, 
Wong, and Hobbs. "Effective discipline means that the classroom is relatively free from confusion, disorder, and anti- social behavior (Mills, 1997).” Lee Canter and Harry Wong emphasize that one must be consistent with their course of action with every child.

Purpose

As many teachers plan their daily lessons and maintain the classroom, one area of hardship is that of effective classroom management. According to Harry Wong, many times professional educators strive for discipline when what they really need is procedure. The problem is that a procedure needs to be rehearsed and known by all. It must be rehearsed over and over again and followed through and equally applied to each student.

Classroom management should be designed to reflect behavioral expectations and create an atmosphere in which student self-esteem can flourish (Canter, 1992). Educators have the right to maintain optimal learning in an environment free of disruption. Students also have rights as learners to learn in an appropriate environment free of bias and disruptions. In the past, the term discipline has been used to refer to classroom management, but it implied a negative connotation that is equated with punishment. Instead, it should address their future decisions. According to Mills, discipline is an instrument that molds, shapes, corrects, and inspires appropriate behavior. It is an opportunity to redirect students. For purposes of research, the term classroom management will be used rather than discipline. Classroom management will include ways to effectively reduce misbehavior in the classroom setting. 
Everyday, educators encounter various types of classroom disruptions, but are uncertain how to effectively deal with each incident and maintain learning. Each encounter is different because each child is different. Because each child and incident is different, it is hard to determine the techniques that will work for each child and offense; what worked in the past may not work now. The questions the researcher seeks to answer are what current classroom management techniques appear to be effective? Does an effective behavior management policy impact student morale? How does a person design an effective behavior management policy?

\section{Methodology}

This anecdotal research project will take a look at the history of the discipline plan currently used at the Young Men’s Christian Association (YMCA). The researcher is interested in reducing misbehavior in the classroom. The YMCA has had a goal of preventive discipline and working with children to help them make positive choices that will impact their lives. While preserving the past, enriching the present, and inspiring hope for the future, the researcher will evaluate, identify, and examine effective classroom management techniques. The research will require an evaluation of the current behavior management policy in order to identify the areas of concern. Upon the completion of evaluation an implementation of effective techniques will begin in hopes of improving the current behavior management policy. 


\section{Biblical Integration}

“Good classroom order and Scriptural Discipline start with a teacher who says, 'I can do all things through Christ which strengthen me’ (Phil. 4.13) (Hobbs, 1986).” According to the Women's Study Bible by Thomas Nelson discipline is a process that helps the person mature in Christ and know God's will. “To nurture and control children demands enough firmness to correct the unacceptable behavior (Prov. 22.15) but not so much as to injure or damage a child (Eph. 6.4)(Nelson, 1995, p.1040).” According to Proverbs 13.24 discipline should be delivered promptly at the time of the offense, catching wrong behavior patterns before they become set.

Proverbs 22.6 says, “Train up a child in the way he should go, and when he is old he will not depart from it.” Behavior management may sometimes be a part of discipline; there is much more involved to bring students to a point at which they are able to determine for themselves how to make the right choices. Discipline done according to biblical standards provides an umbrella of protection in which a child learns to obey God during times of vulnerability. Loving educators should exhibit firmness, tenderness, kindness, and gentleness no matter what the child's behavior. Correction shows children the error of their way and pulls him or her in the right direction. When disciplining, a child should be taught why a particular behavior was wrong (Col. 3.25) and that the authority violated was not just the educator's, but God's.

The purpose of discipline is to express loving concern (Prov. 13.24), to teach (Prov. 10.13; 29.15), and to underscore responsibility of the individual for personal 
attitudes, actions, and reactions (Ps. 53.3; Jer. 17.10; Ezek. 18.4,20; Rom. 3.10,23; Col. 3.25). Each educator desires that discipline will offer hope for effective development of their students (Prov. 19.18). Discipline is not set up to inflict harm on students but in order to break the willful disobedience of the child and aid in obtaining knowledge (Prov. 20.30; 22.15). The final purpose is to save the child from eternal punishment (Prov. $23.13,14)$.

The guidelines for discipline are to temper firmness with tenderness (Prov. 4.3; 15.32), explain the offense for which they are being punished (Prov. 4.4, 11), and avoid unnecessary severity (Eph. 6.4). When dealing with a child who has misbehaved, reflect grief to the child so they are able to see that you are affected by their act of disobedience (Prov. 17.25; Jer. 4.18, 22; Matt. 23.37; Heb. 3.10, 17). After administering the consequence, reiterate the reason for the consequence and restore the relationship (Ps. 51.7-12). Much prayer, patience, and perseverance are needed to be a teacher with the right mixture of love and discipline.

The Bible clearly models obedience and disobedience. The models of obedience are that of Samuel's parents and Samuel as a child (1 Sam. 2.11, 18; 3.1). Samuel's parents worshipped the Lord diligently in order to be a biblical example that he could see. They also stayed true to their vow to give Samuel to the Lord's service. Even as a child, Samuel was under the leadership of Eli and ministered to the Lord. He had a heart of obedience and responded to Eli's instruction explicitly because he was following the example of his parents. The results of his obedience were that he was a blessing of the 
Lord to his parents (1 Sam. 2.20, 21); he "grew in stature, and in favor both with the Lord and men” (1 Sam. 2.26), and he was God's spokesman to the people (1 Sam. 3.21-4.1).

The biblical models of disobedience were that of Eli and his sons in 1 Samuel. Eli disobeyed the Lord's command concerning His sacrifices and offerings, he put his sons before his service to the Lord, and he did not discipline his sons. Eli's sons despised the Lord because of the example of their father; they disobeyed moral laws and their father, which was a direct violation of the Lord's law. The results of their disobedience were that Eli's sons were corrupt and did not know the Lord, his sons' disobedience caused the Lord's people to sin, Eli brought judgment on his house, and the deaths of Hophini and Phinehas occurred the same day.

\section{Application to Current School}

In the author's present educational environment, classroom management can be applied in several areas. The first area of application is that of consistency with each child and not allowing one to get away with something that another child did and got reprimanded for. Another area seems so simple, but it is easy to play favorites when reprimanding unwanted behavior. The other area of investigation is to say what you mean and mean what you say with every child no matter who they are. Implementing the effective plan of discipline is another area of application at the YMCA. The key to an effective plan is to get parents and administration to support what is being done through clearly stating rules, consequences, and rewards from the beginning of the year. It will not be easy to get parents totally involved, but by giving them what is expected, it will 
help them to realize where the author is coming from.

Every day within the setting of the preschool classroom, children are striving to receive their fair share of the teacher's attention. Various types of behaviors are occurring in hopes of receiving that attention. Some misbehaviors include fighting, throwing objects across the room, disrespect, and noncompliance to the classroom procedures.

At its best, discipline is about guiding and teaching young people, helping them to make wise decisions about their behavior, and allowing them to gradually accept responsibility for their choices and actions to choose (or not to choose) a certain behavior because they understand its consequences, not because a policeman is lurking in the vicinity (Nelson, Erwin, Duffy 202).

Instead of looking at behavior management as a negative aspect and sending kids to time out, the author desires to improve upon the current policy, implementing more effective techniques that will enable students to make responsible choices. The current policy contains areas of inconsistency and ineffectiveness. By implementing these improvements it will allow students a more consistent affirmation of their choices.

Summary

“Discipline is necessary for proper character development, academic study, living with others, personal habits, physical development of the body, perfection in the development of God- given talents, and training in every other area for the child of God (Hobbs, 1986).” The continued use of techniques implemented will enhance the behavior management policy. The data collected will be able to show how implementing new 
techniques improves student morale. It will also illustrate how to effectively put into operation an effective behavior management policy. Finally, the research will indicate the techniques that appear to be effective.

The best way for a Christian to respond to the issue of discipline is to first look to the Lord for daily guidance. We must then realize that our attitudes need to be that of power and love as in II Timothy 1.7. By having this type of attitude, the discipline will be done in love and not because of power. Our purpose is to aid in molding, shaping, correcting, and inspiring appropriate behavior in order to redirect each student toward God's will in his or her life. 


\section{CHAPTER II: Review of Literature}

Many researchers feel that classroom management is an ongoing process, not completed in a day, but requiring patience. Wong (2001) defines classroom management as "all the things that a teacher does to organize students, space, time, and materials so that instruction in content and student learning can take place” (84). However, many researchers feel that in order to be an effective teacher one must have an effective management plan. Sixteen out of twenty- eight sources used by the author hold to the belief that the key to effective classroom management is an effective management plan. The debate is concerning different aspects of the classroom management plan such as rules, rewards, consequences, a support system, and age appropriate techniques for the Early Childhood classroom.

Many of the answers to the above mentioned concerns depend a lot on the researchers' original research conducted and professional experience as educators. Those who have conducted research in the area of classroom management feel that the dreams of having an effective classroom management plan exist in educators, administrators, and parents alike. However, more recent research seems to point to the idea that students are bringing with them more uncertainties and lack of parental support needed to succeed, and implementing an effective plan is increasingly harder to develop. Although the author will attempt to focus her research on the preschool years, this review of literature will also examine effective classroom management plans at the elementary level as well. 
This review of literature will also attempt to outline developmental differences to be considered when creating an effective classroom management plan.

In an article by Stephen Papesh entitled “The Five Be’s for Educators” it is suggested that teachers determine what the student is bringing with them to class by their face and physical appearance. Letting them know that education never ceases was a resounding theme from Canter, Gurian, Wong, and Hobbs. "Effective discipline means that the classroom is relatively free from confusion, disorder, and anti- social behavior (Mills, 1997).” Lee Canter and Harry Wong emphasize that one must be consistent with their course of action with every child.

Much of the research suggests that along with roadblocks, many misconceptions exist regarding classroom management. The main misconception found was that the more motivating, exciting, and academically appropriate our curriculum, the fewer behavior problems. Papesh suggests that every lesson should be 'special'. This implies that if one is prepared you are not asking for trouble. Education should be exciting and conducted with enthusiasm leaving children with the feeling of not wanting to miss class. Lack of sufficient training regarding current methods and techniques is another misconception.

Canter suggests that students as well as educators have rights within the classroom setting. "You have the right to teach and your students have the right to learn in a classroom free from disruptive behavior- a classroom that both reflects your own behavioral expectations and creates an atmosphere in which students' self- esteem can 
flourish” (Canter, 5). Students have a right to a teacher who sets firm and consistent limits, to a teacher who will provide positive encouragement that motivates, to a teacher who will take time to teach them how to manage their behavior, and to know what is expected of them. Teachers' rights consist of the right to establish rules and direction, to teach students to follow rules and direction throughout the year, and to ask for assistance when support is needed. All of the above mentioned teacher rights will be discussed in further detail later on in the review of literature.

According to Hobbs, effective discipline begins with a teacher who says "I can do all things through Christ who gives me strength” (9). Educators as well as students have an occasional bad day, but no matter what happens, educators should always model appropriate ways to express their emotions. Gurian also suggests that the best method of student discipline is to help the child deal with emotional and attachment stress. The teacher should act in a professional manner. Always remember that you are the adult in the classroom and not a teenager. No matter how your students act, conduct yourself as a mature adult setting an example for them. Warner's book, Preschool Classroom Management, suggests that educators’ relationships with children, when positive, will allow students to develop a sense of initiative, which eventually will lead to an "I can do it” approach to living.

"Approximately one- half of all classroom time is taken up with activities other than instruction, and discipline problems are responsible for a significant portion of this lost instructional time” (Cotton, 1). Hobbs agrees with Cotton and also gives vital 
suggestions for increasing learning. First and foremost, he and others agree that being prepared includes heart, mind, body, and classroom preparation. Being ready for students begins with establishing an attitude of "I can”, getting plenty of sleep, and having materials and bulletin boards ready. Affirmation of who is in charge is the second suggestion. Finally, expect success from students.

An effective educator is one that affects lives according to Wong. To be effective, one must establish control, do the right thing consistently, and influence lives. Hobbs agrees and states that this is beneficial to bring order, peace, and stability to the classroom. Once an educator has become effective, one is ready for classroom management.

Management should be maintained throughout the year with the major task being teaching the rules, consequences, incentives, procedures, and routines of the classroom. “Classroom management consists of practices and procedures that a teacher uses to maintain an environment in which instruction and learning can occur” (Wong 10). The practices and procedures consist of those things that a teacher does to organize students, space, time, and materials so that instruction and student learning can take place.

Along with management comes the process of guiding and teaching young people to make wise choices about their behavior (Nelson, 202). Thorndike/ Barnhart’s Advance Dictionary defines discipline as "training, especially training of the mind or character; a trained condition of order and obedience” (Capehart and West, 8). Discipline is order as 
opposed to chaos, control as opposed to freedom of movement, authority as opposed to anarchy, for either one or the other will eventually rule (Hobbs, 2). Researchers suggest that discipline in the fullest sense of the word is education that aims at making selfdisciplined individuals. While teaching children it helps them to learn for the future.

Discipline many times brings with it negative connotations of misbehavior inside the classroom. Misbehavior implies that the student has intentionally done something wrong and must be punished (Geiger, 384). Other researchers believe the opposite to be true, that instead of looking at discipline as misbehavior, think of misbehavior as opportunities for students to learn and grow. Nelsen suggests that misbehavior occurs because students are often looking for ways to feel they belong.

Discipline should be conducted to the design of the child. The goal is to train the child so that when they are older, they will not turn away from what you have taught them. In definitive terms, we want them to be moral and godly learners with the tools, discipline, and maturity to consistently make right decisions on their own. The task is large, and needs to be an ongoing process.

\section{Development}

Each child is unique and gifted with limitless creativity, with a special blend of characteristics that makes them precious. In order to maximize the potential in each child, you must be flexible in your discipline process. As you administer discipline, your approach should take into account each child's unique characteristics. 
Part of understanding the child as you discipline is to move from the parts to the whole child. These aspects include personality, temperament, modalities, learning styles, environmental preferences, and gender differences.

Each child is born with a behavioral disposition. As they experience life and training, the personality emerges. Personality research conducted by Capehart and West used the Disc Model by Dr. William Loulton Marston as the learning instrument. This particular model gives valuable insight into those who are people oriented and task oriented. According to their research, the dominant and conscientious are task oriented. The dominant child desires control, so the best way to discipline is by allowing choices; making choices allows him to be "in charge." As educators deal with the dominant child, build a positive, trusting relationship, and show that you believe in them. Students who exhibit characteristics of a conscientious nature generally are not able to be spontaneous since rules are valued. When dealing with this child, discipline with predictability, sensitivity, and tons of encouragement.

On the other hand, there are those who are people oriented, inspiring and steady, and status quo. The inspiring child loves to have fun, and help, is optimistic, spontaneous, and talkative. With this child, discipline with a sense of humor, making it into a game and use phrases like "I wonder if..." On the other end, status quo is reserved. They are your peacemaker and compliant child, often making you look good in front of parents because of their compliant nature. Despite the fact that they are easy going there is a quiet wit about them. It may seem as though this child is easy to discipline, but 
occasionally this child may "getcha”. Status Quo responds best when humor is used (without disrespect), and when given acceptable limits for completing a task.

All students learn best through multi-sensory modality, but each child tends to favor one sense as a tool. The first modality is visual learners who need to see it. The best way to discipline a visual child is to post rules, make eye contact, and behavior charts. Auditory learners need to hear and talk about new information. When disciplining this modality, have them repeat information back to you, use voice inflection, and lower your voice at the end of a sentence. Next in line comes the tactual child who needs touch as they experience life. Tactual learners need to be accommodated by involving them in hands- on activities, allowing use of squeeze balls, and reminders of the fact that manipulatives must not distract. The kinesthetic child loves to move. He is best disciplined by directing and redirecting, utilizing meaningful eye contact, and providing hands- on learning.

Once students take in information through their modality strengths, they need to process information. These processes are known as learning styles. For the sake of this research, the author has narrowed down the many systems for learning style process to four descriptive words: organizers, researchers, relaters, and doers.

Organizers like things to be presented in a logical order. If a teacher is disorganized they may "act up.” They respond well to clearly defined rules and love structure. The best manner of discipline is to provide structure, be predictable, be 
dependable, state instructions clearly, give logical consequences, and be consistent. Unlike Organizers who simply enjoy order, Researchers consistently ask "why" and want to know the reason for it all. They love being objective learners and rarely pose a discipline problem. The best way to discipline them is to be credible, consistent, just, have logical consequences, non- arbitrary rules, and present facts not feelings.

Relaters desire to know the "who" because they are "people" and love to relate to the subject. Problems arise when insufficient people interaction takes place in the learning environment. To best meet the discipline needs of Relaters provide nurturing relationships, fairness, personal interactions, approval, and generous praise and affirmation. Doers are those who desire to be in action while learning through hands- on activities. Doers prefer guidelines to rules, affirmation for natural leadership abilities, opportunities to be the leader, choices, and empowerment when being disciplined.

Whether a child enjoys sitting at a table or a desk in a quiet area with bright light, or sitting on a bed, recliner, a rocker, or on the floor with soft lighting and background noise, these factors effect the learning environment. Many children become a discipline problem because the learning environment is not conducive to their method of learning. Whether they are left or right brained, both sides function together, but the dominant side factors into the discipline scene. "According to the research done by Dr. Rita and Dr. Kenneth Sun from St. John's University there are twenty environmental factors that affect learning” (Capehart et.al, 73). 
Throughout the research process each researcher has come to the realization that each child is unique and learns in different ways. The same may be said of boys and girls when disciplining and meeting their educational needs. "In other words, our teachers are not biased per se, nor should be attacked for being so, they simply do not have enough information to fully apply 'ultimate’ teaching to both girls and boys” (Gurian, 57). First, let us look at typical developmental aspects and areas in which educators are able to meet the needs of boys. Boys tend to show aggression, so put that high energy to use by assigning them jobs to do. Also they tend to use more non- verbal communication skills to express how they feel. The best way to enable them to express frustration is to utilize a feeling board. Next, they use more space because movement stimulates their brain, thus, make everything experimental. When making learning experimental, boys are able to move around and see how things work. Boys tend to rely on pictures for learning, so personalizing cubbies and posting photos of what is expected will meet these particular developmental needs.

Girls on the other hand, tend to be left brain- oriented compared to boys being right brain- oriented. Girls desire more sensory data, meaning they take in more information through their fingers and skin thereby allowing math manipulatives and puzzles to aid in their tactual modality. They enjoy communicating with educators as well as peers and are able to listen more effectively than boys. Since talking and listening are of great importance to their development they may learn better from a cooperative learning environment. Their behavior does not usually interfere with classroom routine but they do need more praise than boys to encourage them to make right choices. Some 
other major ways to help inspire girls to strive to be the best they can be are to intertwine movement games, make science experimental, and encourage them to climb. Finally, they enjoy having their picture taken often and being posted for all to see.

The Plan

Effective discipline begins with friendly, flexible guidelines, reasonable routines, age appropriate behavior standards, and a good example to follow. According to Canter, there are roadblocks to meeting the needs of an effective plan. These include negative expectations concerning ones ability to deal with disruptions and emotional problems relating to broken homes, neglect, drug abuse, and poverty. "Negative behavior is affected by setting, exhibition of child's behaviors, adult relationships, events going on in the classroom, and mood of the adult(s) within the classroom” (Warner, 5). Hobbs also agrees with Canter that as educators try to meet the needs of students they need to be mindful of those things which cause stumbling blocks.

Wong said "It is easier to maintain good behavior then to change inappropriate behavior that has become established” (143), to which Canter and Nelsen et.al agree. The strategy they believe to be the most effective is an effective classroom management plan. "Effective, consistent discipline takes a good deal of thought and preparation but the benefits for your children will be well worth it” (Nelson et. al, 204).

An effective classroom management plan consists of three parts. First of all, rules which must be followed at all times by students. Secondly, positive recognition or 
rewards which are those items that students receive because they followed a predetermined set of rules. Finally, consequences consisting of those things which occur because of non- compliance to rules. Through proper implementation and planning, a plan will be helpful within your classroom. The time it takes to stop and restart a lesson when a problem arises will be lessened.

Since your plan is active, behavior management becomes easier because you are able to respond quickly, assertively, and with confidence. The classroom setting allows educators' as well as students' rights. The plan protects student rights by ensuring each student fair and consistent treatment. Parent and administrative support is crucial to maintain an effective plan. Parents support your efforts because they know their child is cared for. Administrative support is ensured by demonstrating a well- thought out "blue print” for managing behavior.

"The number one problem in the classroom is not discipline; it is the lack of procedures and routines” (Wong, 167). Procedures must become student routines. Wong suggested five procedures that must be taught to students: beginning the day, quieting a class, students seeking help, movement from one activity to another, and end of the day.

When creating an effective plan there are several guidelines to follow. When creating rules for students to follow make sure they are observable and applicable all day. When creating a system of positive recognition, the key to motivating your students for success is to give sincere and meaningful attention along with motivators that encourage 
students to choose appropriate behavior. Finally, rewards should create a positive atmosphere.

Once you have created the plan you must teach it to your students. When teaching the plan, keep in mind three things: explain, rehearse, and reinforce. Explain, simply put, means to create a lesson plan that teaches the rules. Within those lesson plans define procedures by demonstrating appropriate behavior. Once you demonstrate these procedures, check for understanding. Rehearse means to practice procedures under the supervision of the educator. Procedures are best learned when they are practiced until they become routine. Reinforcement is the final step in ascertaining that students have learned the procedure.

If students begin to neglect the procedure, re- teach the correct procedure. When they have relearned the procedure, praise them for acceptable work. Be sure to explain the reason we have rules and consequences.

Now that students have learned the plan it is time to activate your plan. Begin by posting rules, consequences, and rewards for parents and students to see. When a rule is broken, immediately enact consequences. Once you have enacted the consequence it is critical to give positive feedback as soon as you notice the student making the right choice. You want students to know that what you say, you will do every time, so always be consistent. 
Rules

"Effective classroom management is founded on the development of class rules. Helping children realize that every one has a responsibility to develop a 'happy classroom' is an essential component of effective classroom management” (Warner, 3637). Set boundaries for students. By setting these limits students behave better and know how far they can go. At times children will test the limits set forth by rules, and if they discover that you are not consistent, their negative behavior will escalate.

When creating rules keep in mind that you want to aim at creating specific rules compared to general rules. General rules cover a plethora of behaviors and must be explained. Even though they must be explained, they offer flexibility in that a great deal of behavior can be covered. On the other hand, specific rules are to the point and cover one behavior clearly. Thus students know what behavior is expected of them. The disadvantage to specific rules is that they have to be limited to no more than five.

Developing rules can be a difficult job, but if one follows a few simple guidelines it can eliminate the hassle. According to Bosch, one should not use more than five rules. Wong, Gurian, and Canter all agree that not more than three to five rules should be used because people generally have an easier time remembering numbers in groups of three to five. Some other things to consider are to state rules clearly, keep it simple, state rules positively, and teach them. Some examples of specific rules are "use your walking feet" and "keep hands and feet to yourself”. Once you have established rules they must be taught. 
Involving students in the process of making rules will help them to remember what is expected of them. When teaching rules it is best to use the "I do it, we do together, and you do it" method where they watch you model the behavior, you all do it together, and then they do it alone. Educators need to be watching for non- compliance and at those moments re- teach, reinforce, and review rules. When rules are broken, immediately correct the problem, implement consequences, and converse with the child. Students know they are cared about when you say what you mean and mean what you say. "Remember classroom rules must be designed to teach appropriate classroom behavior" (Canter, 53).

Rewards

"The truth is under the stress and strain of the classroom educators tend to react negatively to pressure" (Canter, 60). Research shows that "skillful use of positive recognition means utilizing different approaches for individual students and situations. It means assessing each situation on its own merits and deciding how you, as the teacher, can best meet a student's needs” (Canter, 76). Reinforcement should be used often but at appropriate times. "Appropriate behavior is maintained when children are told that what they are doing is what is expected" (Essa, 34). When educators implement a change in behavior they must remember that something else is being taken away.

The goal of class-wide recognition is to have a means to motivate students to learn new behavior or to work on a problem. When using class-wide recognition Canter 
says to make use of peer pressure. Peer pressure can be effective when working on a specific class-wide problem.

Many educators reject rewards because they feel as though students will not be self- disciplined (Kohn, 29). Kohn believes that rewards only teach children to act in the desired way in order to receive the former praise or to avoid consequences. Canter, Gurian, and Wong disagree with Kohn's view on rewards. They all believe that rewards encourage students to continue appropriate behavior. Secondly, they believe that rewards increase self- esteem because students are reinforced for appropriate behavior. "The best way to build responsible student behavior is to continually provide frequent positive recognition to those students who are on task” (Canter, 146). Rewards need to be appropriate and achievable within time constraints set forth by you, as the educator. Rewards that are used should be things you are comfortable using, for instance, stickers, computer time, a special movie, theme days, and take home treats. Once you give points toward the goal do not take them away (Canter).

According to Wong, there are two types of rewards- simple best and logical. Logical rewards are those that institute privileges such as first dismissed to recess, participation in a special event, student of the week, or very important person certificate. Simple best are those which a student can not touch but affirm appropriate behavior. Some examples are a simple smile, high five, pat on the back, encouragement and praise, and "warm fuzzy" notes. "Make praise the most consistent positive reinforcement 
technique you use. Start thinking now about all the opportunities you have each day to recognize students’ success” (Canter, 151).

Canter agrees with Wong in that students are encouraged with these two types of rewards. It is his belief that tangible rewards are not a bribe given in anticipation of a behavior (65). Rewards are given as a result of a behavior whereas bribes are used to entice someone to do something they normally would not do. “A positive phone call or note home is one of the most time effective means of getting parents on your side- of letting them know that you care about their child and want to share their child's success” (Canter, 64).

Consequences

What are consequences, how do they benefit students, and are there guidelines for implementation and use? Simply put they are something students do not like, but are never physically or psychologically harmful. They are also a choice that does not have to be severe to be effective (Canter). Always deal with the behavior, not the person; you leave a person's dignity intact when you deal only with the behavior issue. Consequences benefit students in that they understand the need for self- control. Gurian, Wong, and Canter believe that consequences set limits for educators as well as students. When providing them, stay calm and be matter of fact. Always be consistent! After a student receives consequences, find an opportunity to recognize positive behavior. Provide an "escape mechanism” for the upset child. When disruption continually occurs 
"move in", proximity to the student is a must. When your authority is challenged remain calm.

According to Gurian's research the proper balance between warmth and discipline is often hard to find, especially by novice teachers (Johnson, 1994). How many times has it been said that "for every action there is an equal opposite reaction”? "For every inappropriate behavior, there is an alternative appropriate behavior” (Warner, 159). "There is perhaps nothing more harmful we can do to children than allow them to disrupt or misbehave without showing them we care enough to let them know their behavior is not acceptable. Students need to learn that inappropriate behavior carries with it very real consequences” (Canter, 79).

It is the belief of Wong that "more time should be spent discussing consequences because a person's life, at any given point, is the result of that person's actions” (152). Consequences need to be explained to students, so that they in turn will have a better understanding of what is expected of them.

Behavior patterns exist in each child and are influenced by many contributing factors. Behavior patterns in children are developed based on individual reasons including genetic factors, health factors, family interactions, and personal history. Behavior patterns change based on what follows the inappropriate behavior. 
As educators you seek to affect inappropriate behavior, but the truth is that there are certain factors you are unable to affect. The truth is you will not be able to change health problems, allergies, poor nutrition, sensory deficits, lack of attachment, as well as family stress. These factors are beyond our scope of expertise. Even though you may not be able to change the whole child there are factors you can affect. Those factors are physical environment, inappropriate expectation, awareness of developmental stages, inconsistent messages, and oversensitivity to stimulation. "Most children thrive on an appropriately stimulated environment, but for some, the color, the noise, activity level, and movement can be overwhelming” (Essa, 23).

Consequences are not punishment and they may not necessarily be positive or negative. Students as well as educators believe that nothing is wrong until they get caught. Positive consequences are rewards that result when people abide by the rules and those that happen without educator intervention. On the other hand, negative consequences are penalties that result when people break the rules and results in educator intervention. For example, they may include time out, fines, detention, last to leave, deprivation of some reward, and exclusion from class participation. "By focusing on students, who are not following directions, a teacher can create a negative environment in the classroom” (Canter, 142). Students need to learn that negative consequences are a natural outcome of inappropriate behavior. By using them you show your students that you not only care about their behavior, but that you also care about them as unique individuals. 
How you as an educator react to misbehavior in the classroom can escalate or calm the situation. Your response will impact students' self- esteem as well as success. Canter's research concluded that there are three types of response styles that an educator falls into. First of all, a non-assertive educator is passive and inconsistent. Students of a non- assertive educator feel frustrated, manipulated, and angry. Secondly, a hostile educator's response is hostile, rigid, and authoritarian. Students feel they are unfairly treated by the educator. Finally, an assertive response is one in which educators clearly, confidently, and consistently state expectations. Students who sit under the teaching of an assertive educator learn to trust and respect themselves as well as others.

As one considers a discipline hierarchy there are several things to keep in mind. A discipline hierarchy is a predetermined set of actions that one will follow as a student becomes noncompliant to classroom rules. When listing consequences it is best to list them in order in which they will be imposed. Provide consequences that are easy to implement and non- time consuming. In rare cases when a student is uncontrollable implement a severe clause.

Methods

Research indicates that when creating a democracy educators should allow choices. "When you give students choices, they learn that they can be in control of what happens to them" (Canter, 84). When students are given choices they feel as though they have freedom to participate in group decisions and a sense of belonging. "Choices empower a child, meeting the need for power and belonging in acceptable ways” (Nelsen 
et. al., 16). Assigning classroom duties aids in student self- esteem but be sure to rotate them weekly. When a problem arises, hold class meetings to involve students in fixing the problem. Class meetings are great for students to express feelings and input their ideas as to how they feel the class should be run.

According to research done by Geiger, the most effective strategies are praise, approval and/or reward, and planned ignoring. Ignoring attention-seeking behavior may be hard to do at first, but by asking students to be involved in creating the management plan, the need to ignore will lessen over time. Explain the reason for the appropriate behavior as well as why they need to maintain appropriate behavior. Changing strategies when dealing with misbehavior can greatly impact how students respond. For example, lower or raise your voice, pause and change your proximity to the student.

“A child must deal with hurt feelings before he can move forward to find solutions to the problems his behavior may have caused (Nelsen et. al, 162)”. On the other hand, Hobbs believes that assigning seats, detention, parent contact, asking why questions, and name dropping work the best. Questions challenge a student's mind by asking them why they think....is taking place. Asking "what" and "how" questions encourage students to focus on accountability as they explore what happened, what caused it, feelings, and how they could make the right choice next time (Nelsen). 


\section{Class Meetings}

The purpose of a class meeting is to encourage one another while learning communication skills and developing judgment and wisdom. The focus of these meetings is to learn and practice mutual respect, learn to encourage and support others, time for planning and sharing, and students helping with solutions. Class meetings give children a chance to talk about alternative behaviors.

When conducting class meetings begin by giving compliments and appreciation for students on task behavior. Compliments focus on one child at a time. At each class meeting choose a "child of the week" and have each child say one nice thing about that child. Empower children to help each other. Helping others allows each one to make suggestions about the problems that exist. Then solve problems that affect the group and plan future activities.

Time- out

Time- out is the most widely used technique in the classroom setting. Primarily it is used when children hurt or potentially hurt themselves or others. Designate an area for time- out and remember a rule of thumb is to keep a child separated from the group one minute for each year old. Using a timer will allow students to know when they may return to the group. "Time- out, effectively used, is an opportunity for children to feel better” (Nelsen et al, 210). 
Educators need to remain calm when removing an aggressive child from the group. While removing the aggressive child let them know they may not hurt others. Once a child is placed in time- out do not talk with or look at the child during time- out. If another child approaches the time- out area explain “(Child’s name) needs to be by himself. You may talk to him when he rejoins us again” (Essa). Upon completion of time- out allow the child to rejoin the group and seek to reinforce appropriate behavior as soon as possible.

Often in the preschool setting children tattle on their friends for not sharing, saying no, and so forth. "To eliminate tattling, give children a response that they can use to stop another child's negative behavior” (Warner, 96).

\section{Star Charts}

"Star charts" are visible records of progress. Star charts should be a record of successes, not failures. They work well because students are able to touch and see their progress on a daily basis.

\section{Popsicle Stick}

The "popsicle stick" method works well for those times in which you need help with passing out materials and getting notes to other rooms. Each child's name is placed on a popsicle stick and put in a coffee can. As you need help pull out a stick from the can and then set it aside until all have had a turn. 


\section{Sticker Lady}

"Sticker lady" technique is wonderful for encouraging obedience to rules. As students play, do crafts, and move about, watch for obedience and reward with a sticker. If using this technique, be sure to always have stickers on your person.

\section{Candy Calendar}

“Candy Calendar” by Bosch is a great incentive for students on a daily basis. Each day has a piece of candy on it and throughout the day as students follow rules, obey, and demonstrate good behavior place their name in a drawing. At the end of the day draw a name and that student takes home the candy for that day

\section{Have a Heart}

On a bulletin board in the classroom make a big heart to represent you. Make each child a smaller heart with their name on it. Place all students inside of your heart to begin the day. As they play and interact throughout the day watch for noncompliance. When noncompliance occurs remove that child's heart outside yours. Once they begin to comply with the rules place their name back inside your heart. Have a heart gives students a visual reminder to make the right choice. Explain to students that when they are noncompliant and need to be removed from your heart that it breaks your heart and makes you sad. 
Marble in a Jar

Place a jar on your desk. As students follow the rules drop a marble in the jar. When the jar is full all students receive a reward. If you want to make it interesting you can make a daily goal towards a theme day or special event. Add marbles throughout the day and mark lines for daily goals. As marbles are placed in the jar restate the behavior you are reinforcing.

30/30 Method

This strategy works well for older children. When a student misbehaves give thirty seconds of explanation of inappropriate behavior followed by thirty seconds of telling how special they are as a child. (Capehart).

\section{Student Interest Inventory}

As a new group of students enters your classroom on a yearly basis seek to get to know them personally. Student interest inventories allow you to get to know each child on a personal level. Each student is given a list of questions to answer and return to you. Some possible questions that could be asked are who lives in your house with you, favorite book, color, food, and candy, and what they want to be when they grow up (Canter).

Redirection

Redirection is a simple non- time consuming method for off- task behavior. When students demonstrate off- task behavior continue teaching while cueing students with the 
"look", proximity, and mention the offender(s) by name. The "look" communicates awareness of and disapproval of the behavior. Proximity is standing by the student(s) who are off- task while continuing to teach. Mention off- task students by name while teaching to let them know you are aware of their behavior.

\section{1-2-3 Magic}

1-2-3 Magic is a method created by Thomas W. Phalen used to stop undesired behaviors and start desired behaviors. Phalen compares this model to that of a "Wild Animal Trainer" in that a trainer repeats a method, trains the animal, and repeats the method until the desired behavior is achieved.

The caution when using this method is that the "little adult" that is expected is not a reasonable expectation. A child's reasoning processes are not yet fully developed. The truth according to Phalen is that words and reasons usually do not work. Along with the caution two common mistakes are too much talk and too much emotion. Too much talk leads to persuasion, yelling, and hitting. On the other hand, too much emotion can lead to encouraging the child to continue the behavior in order to get a rise out of the adult. 1-2-3 magic is beneficial in that there is one explanation, authority is non- negotiable, no talking involved, and punishment is short and sweet.

The 1-2-3 magic method is a three step procedure. The first time a student undermines authority or rules, the educator holds up one finger and says "that is one". If the child continues to argue after five seconds hold up two fingers and say "that is two". 
After five more seconds the student is still arguing hold up three fingers and says "that is three take five”. At this point the student is placed in time- out. In severe cases such as hitting or injury to others immediately move to step three and upon returning to the group explain the reason for automatic take five.

There are several variations to 1-2-3 Magic. The first variation occurs when two students are fighting. If two students are fighting, count both students unless there is an unprovoked aggressor or unless you do not see it then do not count it. Another common problem in the preschool setting is tantrums. When a child throws a tantrum when placed in time- out, do not start the time until the tantrum is over.

Much of the research indicates that one should not stop a lesson to deal with offtask behavior. The above methods, when used consistently, will aid in the process of classroom management. One thing to remember is that one technique may be effective for one group of students, but may not be effective with the next group of students.

\section{Support System}

"Relying on control and the power of punishment turns parents and teachers into policemen, full- time enforcers who set the rules then watch constantly for violations” (Nelsen et. Al, 202). A myth about educators who seek support is that if you are competent you never need to go to your principal or parents for assistance. The fact is that parent- teacher relationships enable students to assume the responsibility necessary 
to work to their full potential. "Students do better in school when their parents are involved in their education” (Bosch, 109).

Many parents choose not to get involved because they, as well as the teachers, have fears about the roles education plays in their child's life. Parents fear that their child will be judged or labeled by the educator. Also they are concerned that their child will resent authority because they maintain compliance to rules. The fear also lies with unknown policies and procedures of how the classroom will be run. Many times these fears can be overcome by simply keeping the lines of communication open between school and home. Communication of what is expected and how problems will be handled will ease the fears parents have and let them know that you care about their child. "To assist in acquiring parental support, give the parents a copy of the discipline plan to use as a basis for home- school cooperation" (Wong, 160). "Without parent cooperation, the school's hands are tied, and it is foolish to keep a student in school without full parent support of the policies and program of the school” (Hobbs, 6).

Administrators are your support system when you are in a difficult situation. The first step in gaining their support is to take your classroom management plan to them. Present it in writing with rules, consequences, and rewards. In so doing both you and the administration are able to verify the plan against the handbook. It shows what your plan of action will be for violations and the number of violations before they are sent to the office. Once you present your plan, seek to find out what they will do when a child is 
referred to them. "You and your administrator must work together. The administrator is your ace-in-the-hole for difficult situations” (Canter, 242).

The author has chosen to study preventive disciplinary techniques as a possible solution to effective classroom management. While preserving the past, enriching the present, and inspiring hope for the future, the researcher will evaluate, identify, and examine effective classroom management techniques. Classroom management plans and the results of the author's study will be discussed in further detail in chapter three.

Out of the twenty- eight sources discussing discipline in early childhood, twenty of them agreed that there was a need for an effective classroom management plan in the preschool classroom. These twenty sources also provided suggestions as to how to create and implement an effective plan. The author is confident that she has exhausted the research made available to her and has cited this research throughout her literature review and again in her reference list. The author admits that there may be additional studies not available to her on the topic of discipline. There are also citations throughout chapter three and in the author's reference list. 


\section{CHAPTER III: Procedures and Results}

Presentation of the Problem

It is evident from the research that an effective classroom management plan extends beyond the classroom, and continues long after students have moved on. "The quality of children's relationships with their teacher in preschool is an important predictor of children's future social relationships and academic success in school (Resner Feinberg et al., 1999).”

As Canter (1992) states, students are bringing with them confusion and uncertainty that hinders their motivation to succeed in school. One's expectations of their students will influence them to achieve in the classroom as well as in their lives. When you clearly define and begin to understand why children behave the way they do, an effective classroom management plan can be developed to meet their needs in an appropriate way.

Presentation of the Hypothesis

In order to determine if an effective classroom management plan encourages positive behavior within the classroom, the researcher based her experiment on the following research hypothesis. 
There will be a difference between the observation and implementation sessions. There will be a significant decrease in frequency of disrupting the group, noncompliance, running, tantrums, and clinging.

Subjects

The subjects of this study were the preschool class of three and four year old students at Firestone Park YMCA in Akron, Ohio. There were seventeen in the class. The observation and implementation sessions each consisted of eight weeks and thirty- three days. Each session tracked how often students were hitting, throwing objects, noncompliant, disrupting the group, leaving the room, running, shouting, crying, having tantrums, and clinging. During observation, the classroom daily routine was not changed. The implementation session tracked each behavior with changes made to the discipline plan and classroom routine.

These children were African- American, Caucasian, Hispanic, Vietnamese, and Bosnian from middle to lower class families. Students were randomly brought to our center by way of walk-in, word of mouth, or referral by Children Services Board.

Throughout the experiment the researcher tracked the behaviors of all 17 students as a whole. The researcher also tracked the behaviors of four specific students because of their diverse ethnic backgrounds and diverse behaviors in the classroom. Three of these students were boys; the other student was a girl. These students were also from diverse family backgrounds: single parent, split parent, and married parent homes. 


\section{Variables}

Independent Variables

The independent variables in this study are the observation and implementation sessions. The observation session was taught using our current discipline procedures of time- out in order to regain control if he/ she is having a difficult time. Positive

reinforcement (commenting on the child doing the "right" thing) and positive redirection (removing the child and giving him/ her an appropriate activity) were used.

The implementation session was taught using the current discipline plan with several adaptations. The adaptations included, but were not limited to, rewards, biweekly parent newsletter, beat the buzzer, and active parent involvement.

\section{Dependent Variables}

The dependent variables in this study are the frequency rates of all eleven behaviors tracked daily during observation and implementation sessions. Both sessions consisted of tracking identical behaviors.

\section{Procedures}

The researcher began this project by seeking permission from her director to perform the study. The researcher also sought permission from the branch director to make sure he knew what was being done in regard to the changes in the Discipline policy and procedures (See Appendix A). 
There were several reasons the researcher chose to conduct this experiment with the Discipline policy. The first reason was because discipline is a joint effort between parents and the school. If parents know what the procedures are they are able to support the efforts of the teacher. Another reason was due to the lack of consistency between administration and the classroom teacher in this area.

When permission was granted by both the Preschool Director and Branch Director, the researcher gave a letter to parents of students (See Appendix B) as they picked up their child from preschool. The letter's purpose was to inform parents that their child would be participating in an experiment approved by the director of the preschool. Attached to the letter was a consent form (See Appendix C) for the parents to fill out and return to the researcher. Parents were given a brief synopsis of what was going to be researched. Thirteen parents returned the consent forms.

Prior to beginning the experiment, the researcher reviewed videos and literature to find what behaviors are most often found in the preschool setting and what the experts say on how to handle those situations effectively. The literature was more abundant than videos, but all information was beneficial in creation and evaluation of a revised classroom management plan. The researcher identified various techniques that were appropriate and began to observe and implement new techniques.

During the observation session the classroom environment did not change with regard to teaching and classroom management. Each morning began with circle time, snack, craft and centers, and then physical activity. Each day the researcher carried a 
clipboard around with a tally sheet (See Appendix D) and each time one of the students exhibited a behavior, a tally mark would be marked within that particular column. For example, if a student was disrupting the group, the researcher would mark the box one time. As students exhibited these behaviors they were redirected to an appropriate activity or removed from the group for a time- out.

Upon the completion of the observation session the researcher looked at the frequency of each behavior to determine what areas were in need of the most improvement. After looking at the data, new techniques were considered for use with a revised classroom management plan. The techniques used were classroom jobs, a system of rewards, classroom rules, class meetings, Classroom Management Brochure, and various other methods that will be explained.

The researcher began the implementation session differently. The current discipline policy was used but adaptations were made to better meet the developmental and social behaviors of the students. The main adaptations used were a bi- weekly newsletter (See Appendix E), “beat the buzzer”, Classroom Management Brochure, classroom jobs, and background music.

The adaptations were made taking into account the developmental continuum for a preschooler. Prior to beginning implementation of new techniques the classroom environment was rearranged in order to place quiet activities such as library, table toys, and computer away from louder centers such as blocks, trucks, housekeeping, and tool 
bench. Each center was defined using colored masking tape. For instance, housekeeping was defined by a green tape line, while library was defined by red. As the researcher rearranged the room a set location was created for a time- out location. In the past, a child removed from the group was placed in a chair near the staff working on crafts with some students, while the others were playing in centers.

Implementation began by distributing a Classroom Management Brochure to each parent. The brochure was placed on each student's hook along with their daily craft to take home. The brochure explained the rules, consequences, and rewards to be used by the researcher.

Once parents had the brochure, the students were informed of what was going to be done in regards to classroom management. The first week of implementation focused on discussing rules with students. The researcher asked students "Why do we have rules?” They replied by stating no running and no hitting. It was then explained to them that rules are in place in order to protect one another and to set limits. The students were then asked to help create the classroom rules. Their suggestions were no hitting, no throwing toys, no spitting, and no biting. The researcher took notes and combined these suggestions together to create a list of four positive rules. The rules for the classroom became: Follow all rules; Keep hands, feet, and body to yourself; Stop, look, and listen to teacher; No bad words. 
After rules were established, students were led in a discussion about what would take place if they did not comply with the rules they created. The rules were then shown to them on a poster and hung in the classroom for all to see daily. Finally, a discussion was held in regard to compliance of the rules. If students followed the rules they would be rewarded on occasion with a hand stamp, sticker, positive note to their parents, special take home treat, or free choice activity. Each morning during circle time the researcher reviewed the rules, consequences, and rewards with students.

Center time also had a new look as each area was taped off with a different color tape line to identify its exact location. For instance, blocks and trucks were blue and housekeeping was green. Each morning students and the researcher reviewed what color each center was and what belonged in that area.

At times a student felt overwhelmed by centers and would desire to sit off by himself for a few minutes and then return to play with others. Upon noticing this, the researcher implemented the idea of a “cool off zone”, where a student could play alone or just sit, calm down and relax. The activities for this area were play- dough, puzzles, books, flashcards, or table toys. This concept was explained to the class as a whole and they were asked what they would like to have to play with in the "cool off zone.” The responses were amazing and consisted of stuffed animals, books, table, chairs, stools, play-dough, games, chalkboard, and bean bag chairs. 
Their suggestions were taken into consideration and materials were purchased for the area. Once items were purchased the students and the researcher went to work to create an area for students to relax and be separated from the group to calm down. The students aided in placement of furniture and the items to be used.

Throughout the implementation session students were removed from the group for hitting, disrupting, or shouting to a specified time- out location created by students and staff. Upon completing a time- out, the staff member who placed that child in time- out would talk with the student about their actions. Each child was asked questions to make them think about their behavior and how it affects the classroom environment. Some questions asked were "Why were you in time- out?", and “What could happen to your friend or you if you run/ throw toys?" Once they worked through the questions they were asked to apologize for their behavior. The staff then watched that student for the first time they were following the rules after time- out and acknowledged the on- task behavior.

The most frequently encountered behaviors in the classroom were noncompliance and disrupting the group. Noticing the fact that these behaviors were becoming a problem the researcher felt it would be best to allow students to help each other combat the problem. Thus the technique of a class meeting was held in order to get student input on what they felt would eliminate the problem.

As the class meeting began the researcher explained to students the problem noticed in the classroom and asked students,"What do you think would help you follow directions and listen during circle time and throughout the day?” Students responded by 
suggesting to do a wiggle song or to make it into a game. Class meetings were also a time for students to encourage each other. Each student had to say one nice thing about the person next to them before closing the meeting.

The daily schedule was changed in regard to crafts and centers. The changes made were that crafts would be done as a group and centers was then its own time. This change was made in order to have both teachers interacting with students. In so doing, student behavior problems could be headed off before they erupted into a serious problem.

For clean- up, the researcher implemented a game called "beat the buzzer.” Each day students were given a five minute warning before the game would begin. Five minutes later the researcher called out "beat the buzzer.” Students then had to clean up all toys, find their center name, and sit on the circle tape line before the buzzer went off. If they "beat the buzzer" they were rewarded with a tickety- tock stamp. As "beat the buzzer” began students were given ten minutes to clean the room, but once they mastered that time it was then reduced and eventually no reward was given.

In order to make students feel like they had control of one aspect of the classroom, each student was assigned a job. The jobs included snack helper, door holder, line leader, name collector, messenger, cleaner, and circle helpers.

Throughout the experiment, parents of participants were asking what changes were being made and how students were reacting. The reason for asking was because they were noticing a change in their child at home. Because of their questions, a bi- 
weekly newsletter was created. The newsletter contained information about what students were learning, what was happening with regard to changes, upcoming events, and reminders.

The students had a difficult time adjusting to the new classroom management plan at first. The researcher had to be there as students arrived each morning and greet them by name and with a smile to help ease them into the new plan and procedure. As students began to see the consistency of the daily routine they began to comply without resistance.

To alleviate apprehension among students in regard to the rapid changes, the researcher developed a morning question and story- telling time for students. Once they were greeted they were able to tell a story or answer the question of the day. This time allowed them to know they were loved and what they said mattered to the researcher.

Students began to identify reasons for their behavior as well as how it impacted the classroom environment. When students received their stamps and stickers they could not wait to tell their parents. After hearing their children's excitement, the parents' response was extremely positive.

One problem that arose throughout the implementation session was that several new students started in the program. The preschool does not have a cut off date for new enrollment, thus making it difficult to maintain consistency between all students. These 
difficulties took much time and work from the researcher to get new students acclimated to the management plan.

Another difficulty occurred when a child who began the program in the middle of the experiment became extremely aggressive towards staff and classmates. This student would throw toys at others and hit staff and students. Because of the researcher's lack of training in dealing with severe aggressive behavior, much time was lost in protecting other students from harm by this child. If more training had been made available, the researcher would have taken it. Fortunately, no students were harmed by his aggressive behavior.

The researcher used SPSS 13.0 for Windows to run a frequency analysis of all behaviors tracked during both sessions. SPSS 13.0 was also used to run independent ttests of similar behaviors in both sessions.

Results

The results of the differences between the two sessions are shown in the following table. Nine out of ten behaviors showed a significant decrease between the two sessions. Leaving the room showed a significant increase from the observation to implementation session. 
Table 1

Frequency Rates of Ten Behaviors of Two Sessions

Time- out

Observation

187

216

238

36

39

16

25

2

70

75

53
Implementation

160

86

60

25

16

4

0

15

33

53

15

Table 2.1

Mean Frequency of Non- compliance and Disrupting Behaviors in Two Sessions

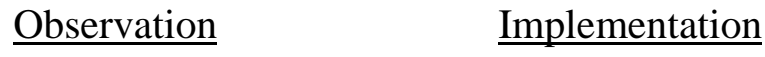

\begin{tabular}{llllll} 
& $\underline{\mathrm{M}}$ & $\underline{\mathrm{SD}}$ & $\underline{\mathrm{M}}$ & $\underline{\mathrm{SD}}$ & $\underline{\mathrm{t}}$ \\
Noncompliance & 6.55 & 5.30 & 2.61 & 2.24 & $3.94 * * *$ \\
Disrupting & 7.21 & 5.10 & 1.82 & 2.08 & $5.63^{* * *}$ \\
\hline
\end{tabular}

$* * * \mathrm{p}<.001$

Table 2.1 shows the mean frequency of non- compliance and disrupting the group.

Table 2.2

Mean Frequency of Crying and Tantrum Behaviors in Two Sessions

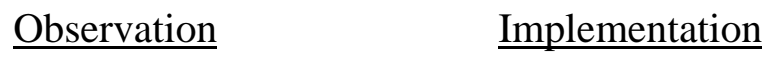

$\begin{array}{lccccc} & \mathrm{M} & \underline{\mathrm{SD}} & \underline{\mathrm{M}} & \underline{\mathrm{SD}} & \underline{\mathrm{t}} \\ \text { Crying } & 1.18 & 1.49 & .48 & .83 & 2.35^{*} \\ \text { Tantrum } & .48 & .67 & .12 & .49 & 2.53^{*}\end{array}$

$* \mathrm{p}<.05$

Table 2.2 shows the mean frequency decrease of tantrums and crying. 
Table 2.3

Mean Frequency of Clinging Behavior in Two Sessions

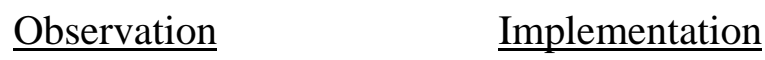

$\begin{array}{llllll}\text { Clinging } & \frac{\mathrm{M}}{.76} & \frac{\mathrm{SD}}{1.70} & \frac{\mathrm{M}}{.00} & \frac{\mathrm{SD}}{.00} & \frac{\mathrm{t}}{2.56 *}\end{array}$

$* \mathrm{p}<.05$

Table 2.3 indicates a significant decrease in clinging.

Table 2.4

Mean Frequency of Leaving the Room and Running Behaviors in Two Sessions

$\underline{\text { Observation }}$

$\begin{array}{lcclcl} & \underline{\mathrm{M}} & \underline{\mathrm{SD}} & \underline{\mathrm{M}} & \underline{\mathrm{SD}} & \underline{\mathrm{t}} \\ \text { Leaving the Room } & .06 & .35 & .45 & .94 & -2.26^{*} \\ \text { Running } & 2.12 & 2.83 & 1.00 & 1.64 & 1.92\end{array}$

$* \mathrm{p}<.05$

Table 2.4 indicates a decrease in running between two sessions. Leaving the room increased rather than decreased.

Table 2.5

Mean Frequency of Hitting and Throwing Behaviors in Two Sessions

$\underline{\text { Observation }} \quad \underline{\text { Implementation }}$

$\begin{array}{llllll} & \underline{\mathrm{M}} & \underline{\mathrm{SD}} & \underline{\mathrm{M}} & \underline{\mathrm{SD}} & \underline{\mathrm{t}} \\ \text { Hitting } & 2.27 & 3.71 & 1.30 & 1.28 & 1.42 \\ \text { Throwing } & 1.61 & 2.06 & .45 & .87 & 2.96^{* *}\end{array}$

$* * \mathrm{p}<.01$

Table 2.5 also shows a decrease in hitting and throwing objects. 
Research indicated that a teacher's active involvement eliminates a student's need to have constant attention from authority. The decrease of these behaviors indicates that allowing students to have a part in creating rules and setting up the way a classroom should be run aids in students making good choices.

While much of the research indicated a decrease in regard to behavior change there was one behavior that increased instead of decreased. Table 2.4 shows the mean frequency of running and leaving the room. Running in the classroom decreased within the two sessions. Leaving the room, on the other hand, was not a significant problem during observation but increased during implementation. The reason for this increase may be that as students were not able to run in the classroom they began to replace running with another behavior. The behavior chosen to replace running was leaving the room.

Individual Analysis

The four students monitored were each chosen for their diverse exhibition of behavior in the classroom. One child from a single parent home showed aggressive behavior during observation, but as implementation began to involve student input he calmed down and would talk to staff about what he was feeling and how they could help him. As the weeks progressed he returned to being aggressive and non- compliant. Each day was spent as though the researcher was in combat to protect other students from his rage. 
His behavior eventually got to the point that if another child looked at him or got in his way he would hit them. When this behavior began he would be placed in time- out where he would throw chairs, throw toys, throw a tantrum, or run out of the building. The director decided to suspend him for two days and upon returning, an individual behavior management plan was put into place. The plan of action stated that the first time he acted out against rules in the previous manner he would be sent home for the day. The second offense was a three day suspension. The third offense would be removal from the program.

His behavior did not stop upon returning from suspension and escalated to the point of destroying YMCA property and running out of the building each time he became angry or did not get his way. He was removed from the program because of his behavior.

Prior to his removal from the program, another child began attending who would injure others as well as himself. This new child was also removed from the center due to his violent behavior and injury to others caused by his behavior. It is thought that he picked up some of the other child's actions in order to get attention that he was not receiving. It is better to receive negative attention than none at all.

Another boy from a two parent home was not fluent in the English language, thus he was chosen as one of the four students. He was able to understand the concept of the rules as the researcher presented information and motions were acted out to aid in his 
comprehension. The behaviors exhibited by him consisted of hitting, non- compliance, and throwing toys.

Each time he hit another child he was playing with he was placed in time- out or moved to another location to play. Two out of seven times he and the child hit were not looking at each other. The hitting may be a result of him trying to communicate with that child. Throwing toys and non- compliance were due to being distracted by others doing the same activity, which is normal behavior for preschool children.

The one girl chosen is from a single parent home. The reason for her being one of the four individual students was due to her shouting, crying, and tantrums due to being tired and not getting her own way. This particular student loved having a part in creating the rules and the cool off zone, but did not like to follow the rules at first.

While playing in centers she would play nicely with others as long as she was getting her way. When she did not get her way she would scream and yell to the point of needing to be removed from the group. When removed she would throw a tantrum and refuse to sit in time- out. It got to the point that her behavior began to escalate to throwing chairs and furniture. Eventually, she did remove herself from the room when she realized she needed to calm down. She would leave the room and go to the director's office. One day she began throwing furniture and wandering away and was sent home. When she left it was explained that this behavior would not be tolerated any longer. Upon 
returning to school she was compliant and began to go to time- out when asked without throwing a tantrum.

The last of the three boys was chosen because of his diverse position of coming from a divorced home. It was hard to track his behavior on a consistent basis as he would not arrive at school until lunch time and then would be picked up at four o'clock each day. The behaviors most often exemplified by him were hitting, disrupting the group, and non- compliance. As with any preschooler his age who does not get his way he hit others out of frustration. He enjoyed talking and being heard by adults, thus he disrupted by talking out or playing with toys or his neighbor.

Non- compliance was expressed by defiance toward authority as well as rules. When he broke the rules by running he would first be redirected. After redirection he would say "I want to listen" and argue hoping to get out of time- out. He would go to time- out, and when questioned about his actions, he knew why he acted that way and how it affected the classroom. 


\section{Chapter IV: Summary and Conclusion}

The results of the assessment showed significant statistical difference between the observation and implementation sessions. The researcher was encouraged with the response to the changes in classroom management. One of the assessments did not show a significant difference, and one other showed a significant difference, but in reverse order of the others. It showed a significant increase in the behavior from observation to implementation.

The researcher believes that the reason for the significant difference being reversed is due to replacing one behavior with another. Preschool age children tend to change behaviors frequently and once they are unable to do one, they replace that behavior with a new one.

Part of the reason for the scores being statistically significant may have been the techniques used to create an effectively managed classroom. These techniques encouraged students to share their opinions and to know that their opinions mattered. They were able to express themselves and know they would not be ridiculed because their suggestions were used in the classroom set up. Assigning each student a job to do allowed them to feel as though they had control of one part of their environment. While students sat in time- out, in a designated area away from the rest of the group, they were able to think about what they did in a quiet location. Upon returning to the group they 
were able to explain why they were in time- out and how it affected or could affect their friends.

If the researcher would repeat this project, she would change several things. First of all, the experiment would need to be conducted over a longer period of time. The variety of methods used may have overwhelmed students because of the rapid changes taking place. The researcher would introduce one technique and allow students to adjust to that change before introducing another technique.

Second, the researcher would use the aide to help track student behaviors. It was time consuming and difficult for the researcher to implement new techniques and track behaviors of the whole class. The researcher would divide the class in half and have the teacher's aide track half the class while she tracked the rest.

Third, the researcher would have worked on changing one behavior at a time. Preschoolers' behaviors have a rapid change rate and working on more than one behavior at a time may not be in their best interest. Their excitement and enthusiasm for the improvements at the beginning could have been due to having a part in the course of action. The sudden decline of excitement may have been due to the rapid changes made in the daily management of the classroom.

The researcher is delighted about the positive feedback from parents in regard to their child. Almost all of the parents questioned what was taking place on a weekly basis. 
Their questions turned into excitement for the way their child was behaving and how excited their child was about getting a sticker or stamp daily. They all said to continue doing whatever was being done because their child was anxious to come to school.

Assigning students classroom helper jobs was helpful in several ways. First, students were encouraged to take an active part in the daily routine. Then students were able to realize their importance in attending school to maintain the environment. Lastly, they were able to see their leadership potential.

The researcher was not surprised by the parental support because of the discipline plan being given to them in writing. Parents knew what to expect if their child misbehaved. They were able to join in the effort of creating an effectively managed classroom environment through a parent - teacher support system. The communiqué enabled parents to know what changes were being made and what to reinforce in order to support the teacher.

The researcher was surprised by the students' interest in "beat the buzzer.” The students were motivated to clean up each day. The interest of students was evident throughout the entire experiment. Whenever it was time to "beat the buzzer" the students would cheer and get busy cleaning the toys. Each day they would ask "Is it time for 'beat the buzzer' yet?” However, preschoolers get excited when it is time to transition from one activity to another. The cheers may have been because they knew it was time to go outside or to the gym. 
The author would like to state for the record that she feels the students benefited from the use of "beat the buzzer." Not that alone, but in conjunction with other techniques and the consistency by all teachers involved. The students enjoyed playing the game, but also needed to be reminded to take care of the toys when putting them away. It was one technique used to obtain an effectively managed classroom. The use of "beat the buzzer” extended beyond fun and games; it enabled students to work together as a team to complete a task.

The researcher was surprised by the student suggestions for rules and creating the "cool off zone.” The suggestions they made were pertinent to their behaviors at the time of making rules. Their rules were mostly negative in nature and with a little guidance from the researcher they turned into a positive list. The cool off zone requests were for puzzles, play dough, and other items for quiet play.

The author feels that classroom helpers also allowed students to benefit. They enjoyed having a sense of control over an activity, but they learned to be leaders and to help maintain a clean and safe environment to play and learn.

The author would also like to state that she feels student involvement, parent involvement, and the "cool off zone" benefited students. Not these activities alone, but in conjunction with other techniques as they were integrated into the daily routine. Student involvement extended the learning by enabling them to share their thoughts and feelings, while thinking critically about their role in the environment. Parent involvement enabled 
students to know their parents' love and care about what they are learning, causing students to want to make right choices, thus making parents proud. "Cool off zone" allowed students a place to relax and be themselves away from the group. This area enabled students to walk away from an argument and think about their feelings, while learning to recognize personal limits and how to control their emotions and feelings.

At the preschool level, the author agrees with research, that rapid change to the environment can be unsettling. Gradually changing the environment would be more beneficial; allowing students to adapt to one change at time limits the need for adult interaction and constant reward.

The author found through the experiment that preschool students have difficulty learning in an unstructured environment. The students were much more relaxed and excited when the author began greeting them each morning and talking about them each day. These discussions let students know they were loved and cared about by the researcher.

The author also found that consistency in the daily routine is better than continually changing the routine. Students were shown the daily schedule as well as explained the daily expectations. This allowed them to know what would happen from the time they arrived until they were picked up by parents. As the researcher watched, students began comforting each other when they wanted parents and telling others and the teacher what would happen next. There were times of astonishment and fear 
concerning what to do next, but students were able to encourage each other through the times of fear without distraction.

While implementing new techniques, the researcher discovered that she had to be more patient and available to students. At times the researcher desired to move to the next implementation while students were still adjusting to the previous one. The techniques worked much better when the researcher slowed down and began reinforcing the old while beginning a new technique.

The author wrote this thesis because our school students needed to be guided in making the right choices. The author desired to find alternative methods to time- out. The author did not want to use time- out as the only method of discipline. Segregating students in my opinion leaves them feeling angry and bitter because they had to leave the group. Time- out instead was only to be used as a last resort to an inappropriate behavior. The author was unfamiliar with alternative methods and wanted to find new methods and use them effectively and consistently with all. Because of this research and experiment, the author now knows that consistency does not mean saying one thing to one child and something else to another child, but it does mean that you say what you mean and mean what you say. Creating an effective management plan is just like planning a lesson. The instructor must take time to review the objectives and make plans for how to present the material for students to understand and retain knowledge. An effective plan alone is not the answer to helping students make good life- long decisions, but combining effective classroom management with a teacher who loves and cares for their students' well being 
can certainly encourage them to make good choices, increase their love of learning, and enhance their outlook on life. 


\section{Bibliography}

Almeida, D. A. (1995). Behavior Management and “The Five C’s.” Teaching Pre K- 8. 26(1), 88-89.

Arnold, David Harvey., McWilliams, Lorette., Arnold, Elizabeth Harvey. (1998). Teacher Discipline and Child Misbehavior in Day Care: Untangling Causality with Correctional Data. Developmental Psychology. 14(2), 276- 287.

Ayers, William., Dohrn, Bernadine., \& Ayers, Rick (Eds.). (2001). Zero Tolerance: Resisting the drive for Punishment. New York, NY: The New Press.

Belvel, Patricia Sequiera; Marcia, Maya. (2003) Rethinking Classroom Management. Thousand Oaks, California: Corwin Press Incorporated.

Bosch, Karen A., Kersey, Katherine C. (2000) The First- Year Teacher. United States: National Education Association.

Canter, Lee.(1992). Assertive Discipline: Positive Behavior Management for Today`s Classroom. Santa Monica, CA: Canter and Associates Incorporated.

Capehart, Jody; West, Gordon and Becki. (1997) The Discipline Guide for Children's Ministry. Loveland, Colorado: Group Publishing.

Cotton, Kathleen. (2001). School Improvement Research Series. School wide and Classroom Discipline. March 29,2003 from the World WideWeb:http://www.nwrel.org/scpd/sirs/5/cu9.html. 
Evertson, Carolyn M., Emmer, Edmund T., Clements, Barbara S., Worsham, Murray E. (1994). Classroom Management for Elementary Teachers. (Rev. ed.) Needham Heights, MA: Allyn and Bacon.

Essa, Eva. (2004) A Practical Guide to Solving Preschool Behavior Problems (5ed). Clifton Park, New York: Delmar Learning.

Feiden, Karyn. (1991). Parent's Guide to Raising Responsible Kids: Preschool Through Teen Years. New York: Prentice Hall Press.

Gartrell, Dan.(2000). ERIC. Beyond Discipline to Guidance: A Primer on the Guidance Alternative. ED 448889.

Geiger, Brenda. (Winter 2000). Discipline in K Through 8th Grade Classrooms. Education, 121(2), 383-393.

Gurian, Michael. (2001). Boys and Girls Learn Differently: A Guide for Teachers and Parents. San Francisco: Jossey-Bass.

Hannon, Jean. (Spring 2002). No Time for Time Out. Kappa Delta Pi Record, 38(3), $112-114$.

Hobbs, Dayton. (1986). Classroom Discipline A to Z. Milton, Fla.: Gospel Projects Press. Junsen, William R. Ph. D, Rhode, Ginger Ph. D, Reavis, Kenton Ed. D. (1994) The Tough Kid Tool Box. Longmont, Colorado: Sopris West

Lewis, Ramon. (2000). Teaching and Teacher Education. Classroom Discipline and Student Responsibility: The Students’ View. 17, 307-319.

Mills, Dennis W. Ph. D. (1997). Classroom Discipline: A Management Guide for Christian School Teachers. April 20, 2003 from the World Wide Web. Http://www.csrnet.org/csrnet/articles/classroom-discipline.html. 
Nelsen, Jane. (1999). Positive Time- Out. Rocklin, CA: Prima Publishing.

Nelsen, Jane., Erwin, Cheryl., Duffy, Roslyn. (1995). Positive Discipline for Preschoolers. Rocklin, CA: Prima Publishing.

Nelsen, Jane., Escobar, Linda., Ortolano, Kate., Duffy, Roslyn., Sohocki-Owen, Deborah. (2001). Positive Discipline: A Teacher's A-Z Guide. (Rev. ed.) Rocklin, CA: Prima Publishing.

Nelsen, Jane., Lott, Lynn., Glenn, Stephen. (1999). Positive Discipline A-Z. (Rev. ed.) Rocklin, CA: Prima Publishing.

Nelsen, Jane., Lott, Lynn., Glenn, Stephen. (2000). Positive Discipline in the Classroom. (Rev. ed.) Rocklin, CA: Prima Publishing.

Nelsen, Thomas.(1995).The Women’s Study Bible. Nashville: Thomas Nelson Publishers. Papesh, Stephen.(April 2002). The Five Be’s for Educators. The Education Digest, 67(8), 35-36.

Phalen, Thomas W. Ph. D. (1990). 1-2-3 Magic: Effective Discipline for Children 2-12. Glen Ellyn, Illinois: Child Management Incorporated.

Turner, Heather, Watson, Steuart T. (1999). Psychology in the Schools. Consultant's Guide for the Use of Time- Out in the Preschool and Elementary Classroom. 36(2)135-148.

Wong, Harry K. \& Rosemary T. (2001). How to be an Effective Teacher: The First Days of School. (Rev. ed.) Mountain View, CA: Harry K. Wong Publications, Inc. 
APPENDIX A

LETTER OF INTENT

To whom it may concern,

My name is Kelly Victor and I am currently working on my Masters of Education degree at Cedarville University. I look forward to graduating in May 2005. In order to complete all requirements for the Masters of Education degree all students must research, plan, and implement an educational practice or procedure in their current educational setting.

As a preschool teacher at Firestone Park YMCA I would like to evaluate the current classroom management plan and procedures and revise the plan to better serve the needs of the students, as well as parents. Since I began teaching the preschool children I have noticed that time outs are not effective for behavior modification in all children. No child's name or identity will be revealed throughout the evaluation process. The evaluation procedure will be conducted using observation and anecdotal approaches.

The evaluation and implementation process will take approximately sixteen weeks to complete. The sixteen weeks will be broken down into two equal times for evaluation, observation, and implementation. The first eight weeks no changes will be made to the current classroom management plan and procedures. I will observe certain children who exemplify excessive behavior problems, observe how often time outs are used, and document the types of behaviors that resulted in a time out.

Following the first eight week period revisions will be made to improve upon the current classroom management plan. During this time the methods used with out current plan will still be used in addition to some new techniques. These techniques will include but are not limited to incentives for good behavior, behavior bingo, mystery motivators, and behavior contracts.

If at anytime during the research project there are any concerns or questions please feel free to contact me or my Advisor Dr. Steve Gruber. You may contact me at (330) 848-3079. You may contact my Advisor at Cedarville University at grubers@cedarville.edu.

Sincerely,

Kelly R. Victor 


\section{APPENDIX B \\ PARENT LETTER}

\section{Dear Parents,}

I, Miss Kelly, am currently working on my Masters of Education. I am looking forward to graduating in May of 2005, but still need to complete a final project before all requirements are met. In order to meet that requirement I must use the various methods and techniques I have been taught in my current setting.

In order to serve you and your child better I am going to evaluate our current discipline plan and procedures. Upon the completion of the observation a revised plan will be put into practice. As the current plan and the revised plan are evaluated observations will be made regarding your child's behavior and overall classroom morale.

I am seeking permission for your child to be a part of this improvement plan at Firestone Park YMCA. Your child’s identity will remain anonymous throughout the research project. Only information regarding behavior problems and student morale will be identified within the context of the project.

If you have any questions, please contact me at work (330) 724-1255 from 9am6pm. Please fill out the form attached and turn it in to Miss Kelly by October 25, 2004.

Sincerely,

Kelly R. Victor 


\section{APPENDIX C \\ PARENTAL CONSENT FORM}

\section{Research Project Participant Permission Slip}

I understand that my child's class will be taking part in a research project to improve upon the current Discipline Plan and Procedures at the Firestone Park YMCA preschool. I also understand that my child's name will be kept confidential throughout the project. Please sign the top portion if your child may participate and the bottom if your child may not participate.

I, (parent/guardian) give my child, (child's name) permission to participate in the research project being

conducted.

I, (parent/ guardian) , do not give my child, (child's name) permission to participate in the research project.

Please submit to Miss Kelly by October 25, 2004. 
APPENDIX D

TALLY SHEET

\begin{tabular}{|c|c|c|c|c|c|}
\hline & ALL & CHILD A & CHILD B & CHILD C & CHILD D \\
\hline HITTING & & & & & \\
\hline $\begin{array}{l}\text { THROWING } \\
\text { OBJECTS }\end{array}$ & & & & & \\
\hline $\begin{array}{l}\text { NAME } \\
\text { CALLING }\end{array}$ & & & & & \\
\hline $\begin{array}{l}\text { NON- } \\
\text { COMPLIANC }\end{array}$ & & & & & \\
\hline $\begin{array}{l}\text { DISRUPTING } \\
\text { GROUP }\end{array}$ & & & & & \\
\hline $\begin{array}{l}\text { LEAVING } \\
\text { ROOM }\end{array}$ & & & & & \\
\hline RUNNING & & & & & \\
\hline SHOUTING & & & & & \\
\hline CRYING & & & & & \\
\hline $\begin{array}{l}\text { THROWING } \\
\text { TANRUMS }\end{array}$ & & & & & \\
\hline CLINGING & & & & & \\
\hline $\begin{array}{l}\text { ATTENTION } \\
\text { SEEKING }\end{array}$ & & & & & \\
\hline TIME OUTS & & & & & \\
\hline
\end{tabular}




\section{APPENDIX E \\ PARENT BI- WEEKLY NEWSLETTER \\ Miss Kelly's Notes}

February 7, 2005

\section{What's Happening in Our Room}

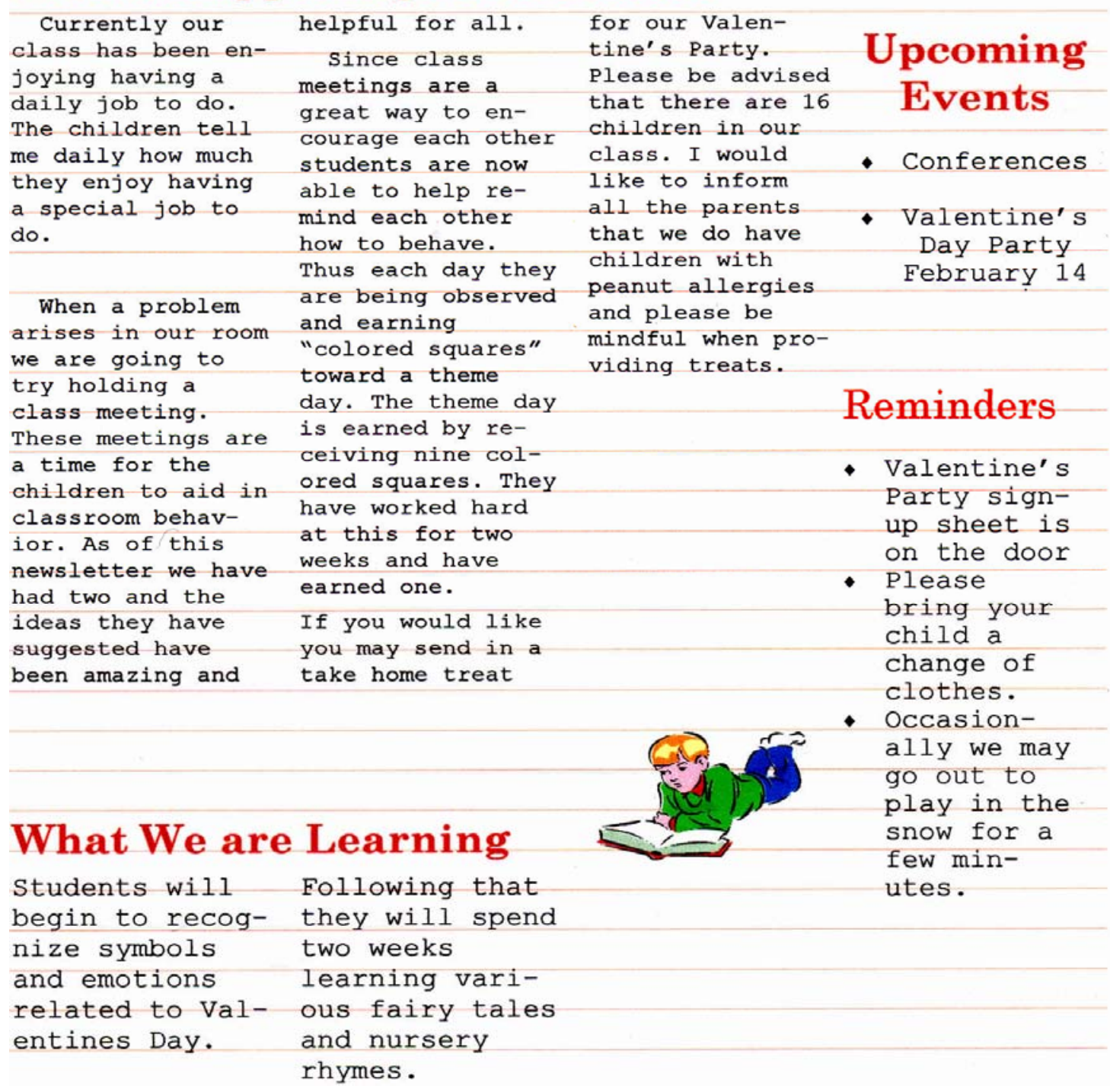


